dr inz. Sylwin Tomaszewski

Instytut Pojazdów Szynowych ,TABOR”

prof.dr hab. inz. Franciszek Tomaszewski

Politechnika Poznańska

mgr inz. Jan Strzemkowski

Instytut Pojazdów Szynowych „,TABOR”

\title{
Influence of selected lubricants on operation of relay valves of braking systems of rail vehicles
}

\author{
Wpływ wybranych środków smarnych na działanie przekładników \\ ciśnienia układów hamulcowych pojazdów szynowych
}

\begin{abstract}
The article presents the relay valve of braking systems of rail vehicles and its functions. Because of their function in braking systems the relay valves should be characterized by high reliability and correct carrying out the tasks in the braking system of rail vehicles. The stand tests of relay valves have shown that the properties of the applied grease have a big influence on the correctness of the relay valves' functioning.

The paper presents the test stand and the results of tests of lubricants used in the relay valves. The idea of carried out tests of the values of lubricants parameters in different temperatures is discussed. The analysis of the test results of the lubricant parameters and the tests of the relay valves on the test stand showed that the correctness of the relay valves operation depends on the properties of the used lubricant. On the basis of the carried out tests, a grease was selected, which especially in low temperatures, meets the criteria of the correct and reliable operation of relay valves in rail vehicles.
\end{abstract}

$W$ artykule przedstawiono przekładnik ciśnienia układów hamulcowych pojazdów szynowych oraz jego funkcje. Przekładniki ciśnienia z racji spetnianych funkcji w uktadach hamulcowych powinny charakteryzować się duż niezawodnościq oraz poprawnym wypetnianiem zadań w uktadzie hamulcowym pojazdów szynowych. Badania stanowiskowe przektadników ciśnienia wykazaly, że duży wpływ na poprawność funkcjonowania przekładników maja właściwości zastosowanego smaru.

Przedstawiono również stanowisko do badań oraz wyniki badań środków smarnych stosowanych w przekładnikach ciśnienia. Omówiono ideę przeprowadzonych badań wartości parametrów środków smarnych $w$ różnych temperaturach. Analiza wyników badań parametrów środków smarnych oraz badań przektadników na stanowisku badawczym wykazała, że poprawność działania przekładników ciśnienia zależy od właściwości zastosowanego środka smarnego. Na podstawie przeprowadzonych badań wybrano smar, który szczególnie $w$ niskich temperaturach, spetnia kryteria poprawnego i niezawodnego działania przekładników ciśnienia w pojazdach szynowych.

\section{INTRODUCTION}

For the proper functioning of entire braking system in every vehicle, which is a part of the train set, there must be the suitable apparatus on it that receives the signals about braking or releasing of the brakes. It is also necessary to unify the requirements for control devices and actuators in order to ensure the correct operation of the brakes of all wagons in the train. This applies to the most responsible braking devices, such as the distributor valve and the relay valve or relay valves of brake cylinders, emergency braking accelerator, weighing valve and anti-slip system [1].

\section{WPROWADZENIE}

Aby cały system hamulcowy funkcjonowal prawidłowo w każdym pojeździe, wchodzącym w skład pociagu, musi znajdować się na nim odpo-wiednia aparatura odbierająca sygnały o hamowaniu bądź luzowaniu hamulców. Niezbędne jest także ujednolicenie wymagań dla urządzeń sterujących i urządzeń wykonawczych w celu zapewnienia popraw-ności działania hamulców wszystkich wagonów w pociagu. Dotyczy to najbardziej odpowiedzialnych urządzeń hamulcowych, takich jak zawór rozrządczy i przekładnik lub przekładniki ciśnienia cylindrów 
The required parameters of the rail vehicle braking system are defined in the relevant UIC leaflets and European standards.

The article presents the exemplary test results of one of the factors affecting the parameters achieved by the relay valve, carried out on the real object. On the basis of the obtained test results, the appropriate changes in the technical documentation of the relay valves were introduced, which ensure that the current requirements are met during the operation and the increase of reliability of its operation, ensuring a high level of safety of the operated vehicles.

\section{DESCRIPTION OF BRAKE CYLINDER RELAY VALVE}

The relay valve is a device used to amplify the pneumatic signal with the required pressure (through the control system) in the cylinder (s). It can be installed at a some distance from the distributor valve on the separate bracket or on a common bracket with the distributor valve (so-called the compact system) or on the pneumatic board of the vehicle (wagon) [5].

Figures 1 and 2 present examples of relay valves from the relay valve family for filling the vehicle brake cylinders and the main pipe of traction units developed and made at the Rail Vehicles Institute "TABOR". These relay valves are usually mounted as the modular apparatus on the pneumatic brake boards of rail vehicles.

In the relay valve construction (Fig. 3) a number of solutions based on actuators, such as pistons sealed with diaphragm transferring the appropriate forces, valves with a rubber O-ring and U-type sealing rings, springs and a precise piston-slide system with a rolling diaphragm the smooth change of pressure in the cylinders as a function of the load. In the construction of this relay valve it is provided for a very wide range of regulation of its parameters in order to adjust its characteristics to different needs and types of rail vehicles [5].

The main element of the relay valve consists of a venting rod connected to the piston (5) and the diaphragm (6). It moves in the body (1), up or down depending on the pressure difference occurring on both sides of the diaphragm (6). The supply air ( $Z$ ) from the auxiliary reservoirs is constantly supplied to each relay valve. When the distributor valve generates a control signal (S), which reaches to the chamber under the lower piston (7) and diaphragm (6), the piston (7) moves upwards and the rod (5) opens the valve (2) via the lever (12), which allows the supply air to enter onto the output side (C) of the relay valve to the brake cylinder capacity. In the opposite situation, when the control signal (S) decreases, the valve closes the supply flow $(Z)$, and the air on the output side (C) of relay valve escapes from the cylinder into the atmosphere through the hollow rod. The pneumatic signal of the weight of the vehicle (W) hamulcowych, przyspieszacz hamowania nagłego, zawór ważący i układ przeciwpoślizgowy [1]. Wymagane parametry układu hamulcowego pojazdów szynowych są zdefiniowane w odpowiednich kartach UIC i normach europejskich.

$\mathrm{W}$ artykule przedstawiono przykładowe wyniki badań jednego z czynników wpływającego na osiagane przez przekładnik ciśnienia parametry, przeprowadzone na obiekcie rzeczywistym. Na podstawie uzyskanych wyników badań wprowadzono odpowiednie zmiany w dokumentacji technicznej przekładników, które zapewniają spełnienie aktualnych wymagań $\mathrm{w}$ czasie eksploatacji oraz podwyższenie niezawodności jego działania, zapewniając wysoki stopień bezpieczeństwa eksploatowanych pojazdów.

\section{OPIS PRZEKLADNIKA CIŚNIENIA CYLINDRÓW HAMULCOWYCH}

Przekładnik ciśnienia jest to urządzenie służące do wzmacniania sygnału pneumatycznego o wymaganym (przez układ sterowania) ciśnieniu w cylindrze (-ach). Może być zainstalowany w pewnej odległości od zaworu rozrządczego na oddzielnym wsporniku albo na wspólnym wsporniku $\mathrm{z}$ zaworem rozrządczym (tzw. układ kompaktowy) lub na tablicy pneumatycznej pojazdu (wagonu) [5].

$\mathrm{Na}$ rysunkach 1 i 2 przedstawiono przykładowe przekładniki z rodziny przekładników ciśnienia do napełniania cylindrów hamulcowych pojazdów i przewodu głównego zespołów trakcyjnych opracowane i wykonane w Instytucie Pojazdów Szynowych „TABOR”. Przekładniki te są przeważnie montowane jako aparaty modułowe na hamulcowych tablicach pneumatycznych pojazdów szynowych.

W konstrukcji przekładnika (rys. 3) zastosowano szereg rozwiązań opartych na elementach wykonawczych, takich jak: tłoki uszczelnione membranami przenoszące odpowiednie siły, zaworki z gumowym pierścieniem uszczelniającym typu O-ring i typu U, sprężyny oraz precyzyjny układ tłoczkowo-suwakowy z przewijaną membraną do płynnej zmiany ciśnienia $\mathrm{w}$ cylindrach $\mathrm{w}$ funkcji ładunku. W konstrukcji tego przekładnika przewidziano bardzo szeroki zakres regulacji jego parametrów w celu dopasowania jego charakterystyki do zróżnicowanych potrzeb i rodzajów pojazdów szynowych [5].

Główny element przekładnika ciśnienia składa się $\mathrm{z}$ trzonu odpowietrzającego połączonego $\mathrm{z}$ tłokiem (5) i membraną (6). Porusza się on w korpusie (1), w górę lub $\mathrm{w}$ dół zależnie od różnicy ciśnień występującej po dwóch stronach membrany (6). Do każdego przekładnika stale jest dostarczane powietrze zasilające (Z) ze zbiorników pomocniczych. Gdy zawór rozrządczy wygeneruje sygnał sterujący (S), który dociera do komory pod dolnym tłokiem (7) i membrany (6), dochodzi do przesunięcia tłoka (7) w górę i trzon (5) za sprawą dźwigni (12) otwiera zaworek (2), co pozwala na przedostania się 
changes the lever ratio (12) between the pistons (7) and (5).

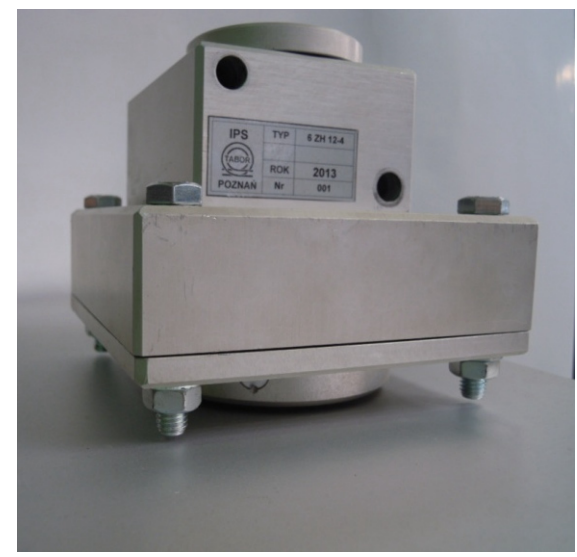

Fig. 1. Relay valve for filling the brake cylinders or main pipe of traction units [5]

Rys. 1. Przekładnik ciśnienia do napełniania cylindrów hamulcowych lub przewodu głównego zespołów trakcyjnych [5]

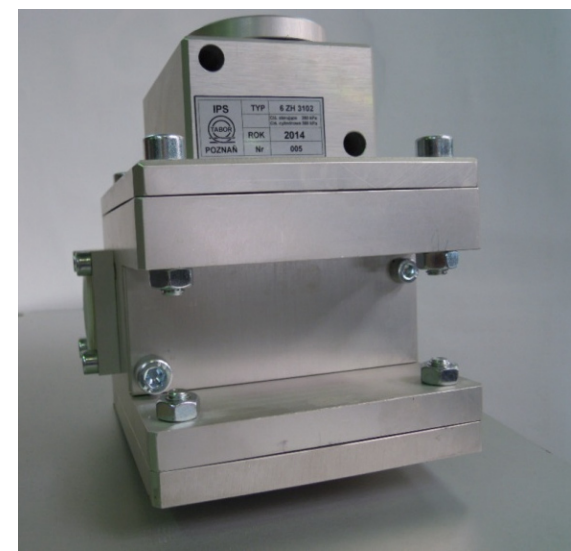

Fig. 2. Relay valve for filling the brake cylinders with regulated ratio [5]

Rys. 2. Przekładnik ciśnienia do napełniania cylindrów hamulcowych o regulowanym przełożeniu [5]

To meet the requirements demanded from the pressure relay valves with a complicated structure, especially those with adjustable ratio and mechanical-pneumatic system of load signal changing, it is essential to make their subassemblies very precisely and to assemble and adjust them carefully. Because of observation of a certain scatter of the relay valve parameters, there was a need to carry out the detailed tests, allowing to determine the influence factors and optimize the structure in order to ensure the highest possible repeatability and reliability of operation of the relay valves. One of the selected factors of influence was the type of lubricants used in the relay valves.

\section{TESTS OF LUBRICANTS USED IN RELAY VALVES}

During the analysis of the operation (functioning) of the relay valves in operation in winter, it was found that there was the increase of failure of these devices during this period. Therefore, it was decided to carry out the correctness tests of the relay valves operation at sub-zero temperatures. powietrza zasilającego na stronę wyjściową przekładnika (C) do pojemności cylindra hamulcowego. W sytuacji odwrotnej, gdy maleje sygnał sterujący (S), zaworek zamyka dopływ $\mathrm{z}$ zasilania (Z), a powietrze znajdujące się po stronie wyjściowej (C) przekładnika uchodzi z cylindra do atmosfery poprzez trzon drążony. Pneumatyczny sygnał o masie pojazdu (W) zmienia przełożenie dźwigni (12) znajdujących się pomiędzy tłokami (7) i (5).

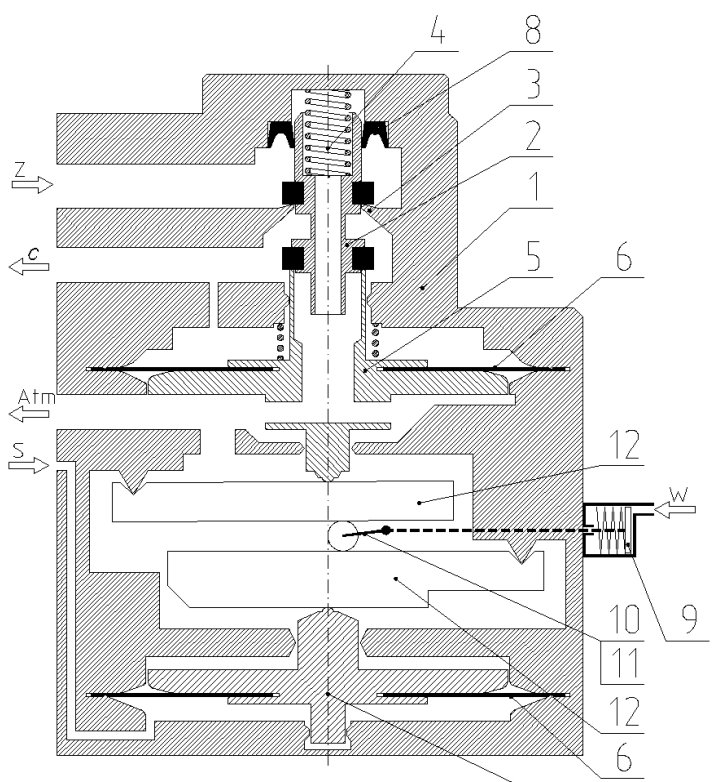

Fig. 3. Diagram of the one-stage relay valve developed by IPS "TABOR" [6]

Rys. 3. Schemat działania jednostopniowego przekładnika ciśnienia opracowanego przez IPS „TABOR” [6]

$\mathrm{Z}-$ Zasilanie /power supply

$\mathrm{C}$ - cylinder /cylinder

$\mathrm{S}$ - sygnał sterujący /control signal

$\mathrm{W}$ - sygnał pneumatyczny o masie pojazdu /pneumatic signal

of the weight of the vehicle

1 - korpus przekładnika/relay valve body

2 - zaworek napełniający /filling valve

3 - siedzisko zaworka /valve seat

4 - sprężyna /spring

5 - tłok górny $\mathrm{z}$ trzonem odpowietrzającym /upper piston with

a venting rod

6 - membrane / membrane

7 - tłok dolny / lower piston

8 - pierścień uszczelniający / sealing ring

9 - układ tłoczkowo suwakowy / piston - slide system

10 - rolka / roller

11 - wahacz / inclined swing lever

12 - dźwignie/ levers

Aby przekładniki ciśnienia o skomplikowanej budowie, zwłaszcza te $\mathrm{z}$ regulowanym przełożeniem $\mathrm{i}$ mechaniczno - pneumatycznym układem zmiany sygnału obciazżenia spełniły stawiane im wymagania, istotne jest bardzo dokładne wykonanie ich podzespołów oraz staranny montaż i regulacja. W związku z zaobserwowaniem pewnego rozrzutu parametrów przekładników, zaistniała potrzeba przeprowadzania szczegółowych badań, pozwalających na ustalenie czynników wpływu i na optymalizację konstrukcji w 
During the tests of the relay valve in the climatic chamber it was observed that the type of the used grease had the influence on the operation of the relay valve at different temperatures due to the changes in the resistances of motion. Therefore, three selected types of lubricants were tested in a climatic chamber.

The lubricant tests were carried out in the Laboratory for Exploitation Materials of the Poznan University of Technology. The measured parameter was the consistency of the lubricant, specifically its hardness index. For the measurements of the hardness of lubricants, a PL-12DC laser penetrometer, manufactured by the Institute for Sustainable Technologies - National Research Institute in Radom, was used, shown in Fig. 4.

It is an automatic device, in which it is used the modern laser technology to measure the penetration. The penetrometer is intended, among others, for testing the consistency of petrochemical products (e.g. lubricants, asphalts, paraffins), food products, cosmetic products, as well as mortars and plastic explosives [2].

The laser penetrometer allows to determine the consistency of the grease. The correct consistency must ensure that the grease does not generate too high resistances. The consistency is graded according to the scale developed by the NLGI (National Lubricating Grease Institute) presented in Table 1. The softer is the grease the lower number is on the scale. During the test, the depth of penetration of the standard cone into a sample of grease is measured in tenths of a millimeter (fig. 5).

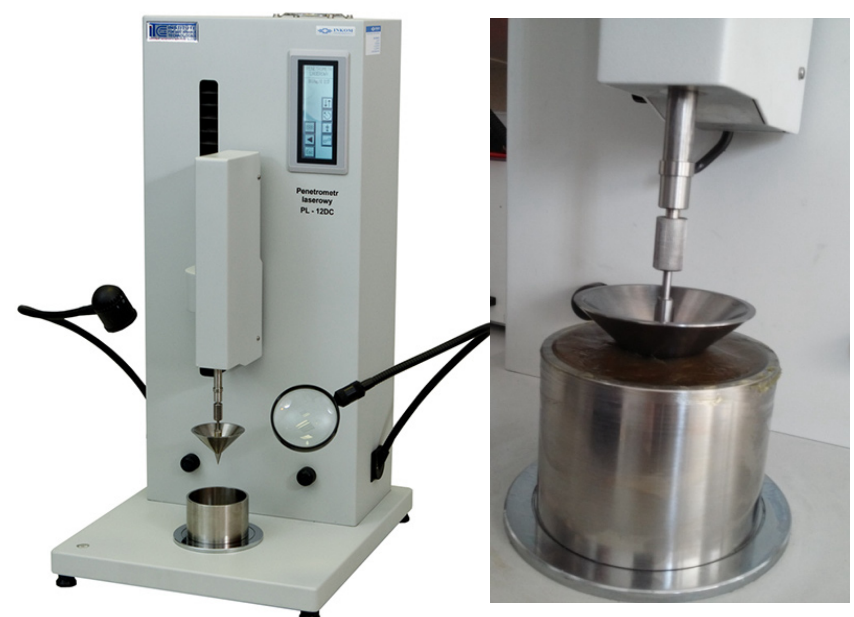

Fig. 4. Laser penetrometer PL-12DC [3]

Rys. 4. Penetrometr laserowy PL-12DC [3]

The following lubricants popularly used in the Rail Vehicles Institute "TABOR" were tested: celu zapewnienia jak największej powtarzalności i niezawodności działania przekładników ciśnienia. Jednym $\mathrm{z}$ wytypowanych czynników wpływu był rodzaj zastosowanych środków smarnych $\mathrm{w}$ przekładnikach ciśnienia.

\section{BADANIA ŚRODKÓW SMARNYCH STO- SOWANYCH W PRZEKLADNIKACH CIŚNIE- NIA}

W trakcie analizy działania (funkcjonowania) przekładników ciśnienia będących $\mathrm{w}$ eksploatacji $\mathrm{w}$ okresie zimowym stwierdzono, że następował wzrost awaryjności tych urządzeń w tym okresie. W związku $\mathrm{z}$ tym postanowiono przeprowadzić badania poprawności działania przekładnika ciśnienia w temperaturach ujemnych.

Podczas badań przekładnika ciśnienia w komorze klimatycznej zaobserwowano, że rodzaj stosowanego smaru ma wpływ na działanie przekładnika w różnych temperaturach na skutek zmian oporów ruchu. W związku z tym przeprowadzono badania trzech wybranych rodzajów smarów w komorze klimatycznej.

Badania środków smarnych przeprowadzono $\mathrm{w}$ Laboratorium Badań Materiałów Eksploatacyjnych Politechniki Poznańskiej. Mierzonym parametrem była konsystencja smaru, a konkretnie wskaźnik jego twardości. Do pomiarów twardości smarów wykorzystano, pokazany na rys. 4, penetrometr laserowy PL-12DC, wyprodukowany przez Instytut Technologii Eksploatacji - Państwowy Instytut Badawczy w Radomiu.

Jest to automatyczne urządzenie, w którym zastosowano nowoczesną laserową technologię pomiaru penetracji. Penetrometr przeznaczony jest m.in. do badania konsystencji produktów petrochemicznych (np. smary, asfalty, parafiny), produktów spożywczych, wyrobów kosmetycznych, a także zapraw murarskich oraz plastycznych materiałów wybuchowych [2].

Penetrometr laserowy pozwala określić konsystencję smaru. Prawidłowa konsystencja musi gwarantować, że smar nie będzie generował zbyt wysokich oporów. Konsystencja jest klasyfikowana zgodnie ze skalą opracowaną przez NLGI (National Lubricating Grease Institute) przedstawioną w tablicy 1 . Im smar jest bardziej miękki, tym niższy numer na skali. Podczas badania mierzona jest $w$ dziesiątych częściach milimetra głębokość wniknięcia standardowego stożka w próbkę smaru (rys. 5).

Przeprowadzono badania następujących smarów powszechnie stosowanych w Instytucie Pojazdów Szynowych „TABOR”:

- "Vecolit EPX 00" - półpłynny smar do przekładni i centralnego smarowania

- "Elf MULTI" - litowo wapniowy smar do łożysk 


\begin{tabular}{|c|c|c|}
\hline $\begin{array}{l}\text { Number NLGI/ } \\
\text { Number of NLGI }\end{array}$ & $\begin{array}{l}\text { Penetracja zgodnie z ASTM }\left(10^{-}\right. \\
\left.{ }^{-} \mathrm{mm}\right) / \\
\text { Penetration according to ASTM }\left(10^{-}\right. \\
\left.{ }^{1} \mathrm{~mm}\right)\end{array}$ & $\begin{array}{l}\text { Wygląd w temperaturze poko- } \\
\text { jowej/ } \\
\text { Appearance at room tempera- } \\
\text { ture }\end{array}$ \\
\hline 000 & $445-475$ & bardzo płynny/very liquid \\
\hline 00 & $400-430$ & płynny/liquid \\
\hline 0 & $355-385$ & półpłynny/semi-liquid \\
\hline 1 & $310-340$ & bardzo miękki/ very soft \\
\hline 2 & $265-295$ & miękki/soft \\
\hline 3 & $220-250$ & średnio twardy/ medium hard \\
\hline 4 & $175-205$ & twardy/hard \\
\hline 5 & $130-160$ & bardzo twardy/very hard \\
\hline 6 & $85-115$ & skrajnie twardy/extremely hard \\
\hline
\end{tabular}

- "Vecolit EPX 00" - półpłynny smar do przekładni i centralnego smarowania

- "Elf MULTI" - litowo wapniowy smar do łożysk

- "Smar TF silikon + teflon" - silikonowy smar $\mathrm{z}$ dodatkiem teflonu.

\section{ANALYSIS OF TEST RESULTS OF LU- BRICANTS USED IN RELAY VALVES}

The results of the tests carried out in the laboratory are listed in Table 2. A graphical image of the change of the consistency of various greases as a function of temperature is shown in Figure 6.
- "Smar TF silikon + teflon" - silikonowy smar $\mathrm{z}$ dodatkiem teflonu.

Powyższe smary zostały zbadane $w$ trzech temperaturach: $24{ }^{\circ} \mathrm{C}$ (temp. pokojowa), $0{ }^{\circ} \mathrm{C}$ oraz $26{ }^{\circ} \mathrm{C}$, które uzyskano za pomocą zamrażarki laboratoryjnej.

3. ANALIZA WYNIKÓW BADAŃ ŚRODKÓW SMARNYCH STOSOWANYCH W PRZEKLADNIKACH CIŚNIENIA

Wyniki przeprowadzonych w laboratorium badań zestawiono w tablicy 2. Graficzny obraz zmiany konsystencji różnych smarów w funkcji temperatury przedstawiono na rys. 6 .

The test results of greases consistency as a function of temperature[6] Tablica 2

Wyniki badań konsystencji smarów w funkcji temperatury [6] Tablica 2

\begin{tabular}{|l|c|c|c|c|c|c|c|c|c|}
\hline $\begin{array}{l}\text { Nazwa smaru/ Name of } \\
\text { lubricant }\end{array}$ & \multicolumn{3}{|c|}{ Vecolit EPX 00 } & \multicolumn{3}{c|}{ Elf MULTI } & \multicolumn{3}{c|}{ Smar TF silikon + teflon } \\
\hline Temperatura/Temperature & $-26{ }^{\circ} \mathrm{C}$ & $0{ }^{\circ} \mathrm{C}$ & $24{ }^{\circ} \mathrm{C}$ & $-26{ }^{\circ} \mathrm{C}$ & $0{ }^{\circ} \mathrm{C}$ & $24{ }^{\circ} \mathrm{C}$ & $-26{ }^{\circ} \mathrm{C}$ & $0{ }^{\circ} \mathrm{C}$ & $24{ }^{\circ} \mathrm{C}$ \\
\hline Pomiar I/Measurement I & 157,4 & 359,8 & 443,2 & 126,0 & 242,1 & 273,1 & 284,3 & 290,0 & 308,8 \\
\hline Pomiar II/Measurement II & 174,2 & 358,7 & 437,5 & 117,0 & 234,5 & 266,0 & 274,3 & 280,2 & 305,4 \\
\hline $\begin{array}{l}\text { Pomiar III/ } \\
\text { Measurement III }\end{array}$ & 160,7 & 369,7 & 446,0 & 136,1 & 229,4 & 263,8 & 290,4 & 291,4 & 306,1 \\
\hline Średnia/Average & 164,1 & 362,7 & 442,2 & 126,4 & 235,3 & 267,6 & 283,0 & 287,2 & 306,8 \\
\hline
\end{tabular}

Figure 7 shows the view of one of the relay valve's elements (valve) with the used Elf MULTI 1 grease and Vecolit EPX 00 grease (used in the relay valve) at temperature $-26^{\circ} \mathrm{C}$. It is clearly seen that the used lubricants, under the influence of low sub-zero temperature, changed their consistency from the liquid into a solid consistency, which is disadvantageous for the correct operation of the relay valve.

The carried out tests have shown that this causes occurrence of large resistances of movement and leads to the suspension of the valve, and thus to the lack of full release of the cylinder and the occurrence of large leak in the power supply system of the braking system of the rail vehicle. The pressure characteristics in the relay valve system during operation with frozen grease and the suspended valve are presented in Figure 8.

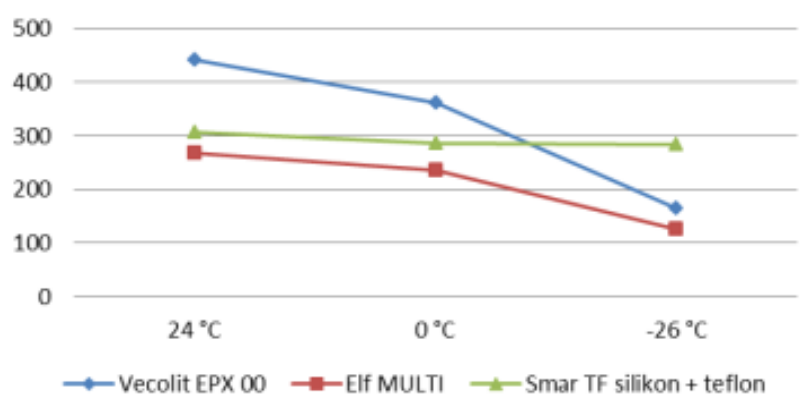

Fig. 6. Consistency of greases as a function of temperature [6] Rys. 6. Konsystencja smarów w funkcji temperatury [6]

$\mathrm{Na}$ rysunku 7 przedstawiono widok jednego $\mathrm{z}$ elementów przekładnika (zaworka) z zastosowanym smarem Elf MULTI oraz smarem Vecolit EPX 00 (stosowanych $\mathrm{w}$ przekładniku) $\mathrm{w}$ temperaturze $26^{\circ} \mathrm{C}$. Wyraźnie widać, że zastosowane środki smarne, pod wpływem niskiej ujemnej temperatury, 

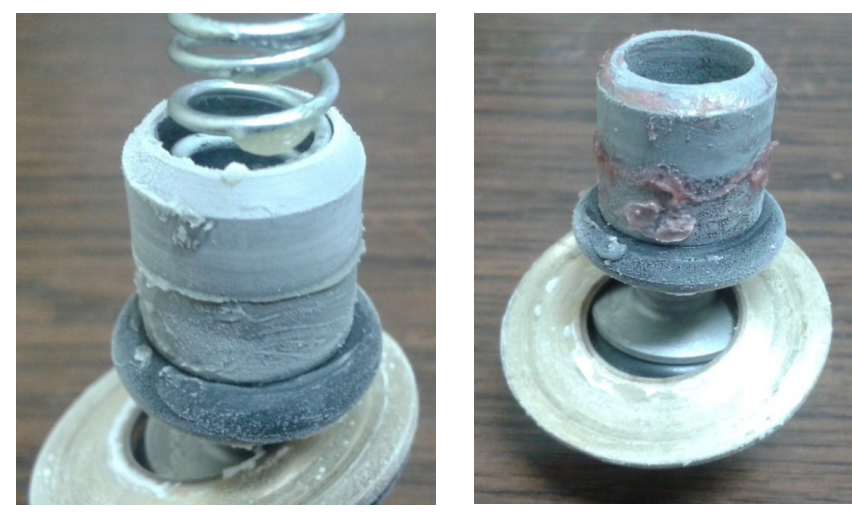

Fig. 7. View of the used Elf MULTI grease (on the left) and Vecolit EPX 00 grease (on the right) in the relay valve operating at temperature of $-26^{\circ} \mathrm{C}[6]$

Rys. 7. Widok zastosowanego smaru Elf MULTI (po lewej) oraz smaru Vecolit EPX 00 (po prawej) w przekładniku działającym w temperaturze $-26{ }^{\circ} \mathrm{C}[6]$

However, Figure 9 shows the valve with the used TF silicone + teflon grease, which during operation at $-26{ }^{\circ} \mathrm{C}$ did not change its consistency and thus provided the correct operation of the relay valve at the sub-zero temperatures.

As a result of the above analysis of lubricants, the previously used Elf MULTI grease was changed for TF silicone + teflon grease.

\section{SUMMARY}

The article presents the test results of lubricants in order to select the agent with the best parameters as a function of temperature, in application to the relay valve.

During the analysis of the test results it was found that the grease used in the relay valve must have the stable parameters in the wide range of temperatures. Especially at low temperatures, it must keep as liquid consistency as possible. Therefore, the silicone grease was introduced in the appropriate systems of relay valve, which has a practically constant consistency in the range of temperature from $-30{ }^{\circ} \mathrm{C}$ to $+40{ }^{\circ} \mathrm{C}$.

On the basis of the carried out tests the grease was selected, which used in the specific elements of the relay valve construction allows it to function correctly and reliably.

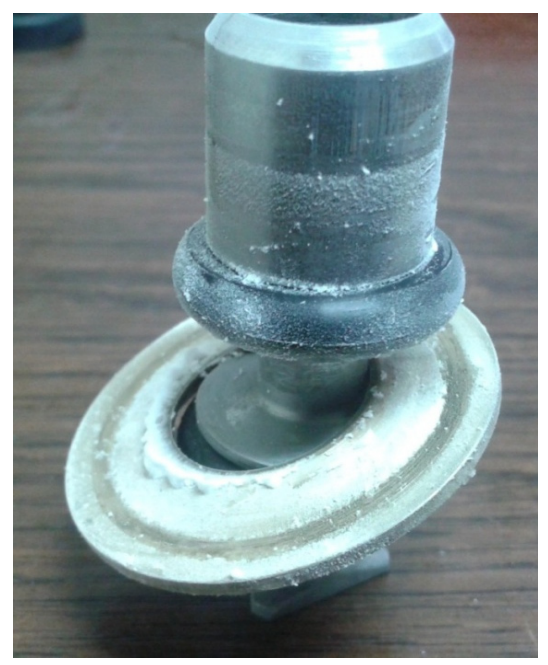

Fig. 9. View of the used TF silikon + teflon grease in the relay valve operating at temperature of -26 ${ }^{\circ} \mathrm{C}[6]$

Rys. 9. Widok zastosowanego smaru TF silikon + teflon w przekładniku działającym w temperaturze -26 ${ }^{\circ} \mathrm{C}[6]$ zmieniły swoją konsystencję z płynnej w konsystencję stała, co jest niekorzystne dla prawidłowej pracy przekładnika.

Przeprowadzone badania wykazały, że powoduje to powstawanie dużych oporów ruchu i doprowadza do zawieszenia się zaworka, a tym samym do braku pełnego odhamowania cylindra i wystąpienia dużej nieszczelności w układzie zasilającym układ hamulcowy pojazdu szynowego. Charakterystyka ciśnień w układzie przekładnika ciśnienia podczas pracy $\mathrm{z}$ zamarzniętym smarem i zawieszonym zaworkiem została pokazana na rysunku 8 .

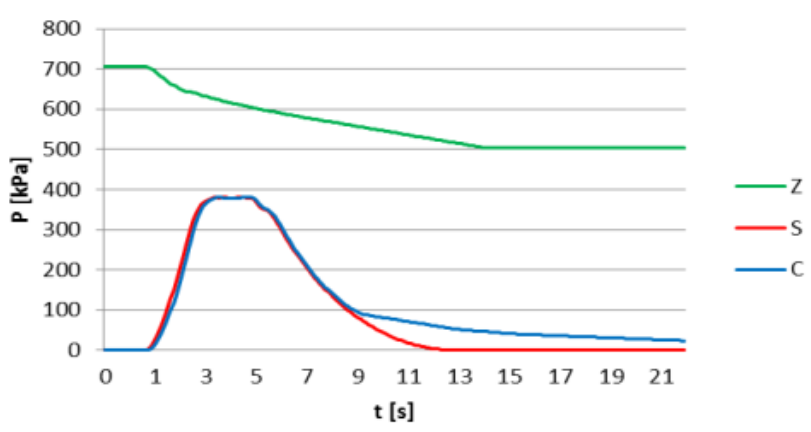

Fig. 8. Exemplary course of the test with a suspended valve of relay valve [6]

Rys. 8. Przykładowy przebieg próby z zawieszonym zaworkiem przekładnika [6]

Na rysunku 9 natomiast przedstawiono zaworek z zastosowanym smarem TF silikon + teflon, który podczas pracy $\mathrm{w}$ temperaturze $-26^{\circ} \mathrm{C}$ nie zmienił swojej konsystencji i tym samym zapewnił prawidłową pracę przekładnika ciśnienia w ujemnych temperaturach.

W wyniku powyższej analizy środków smarnych zmieniono dotychczas stosowany smar Elf MULTI na smar TF silikon + teflon.

\section{PODSUMOWANIE}

W artykule przedstawiono wyniki badań środków smarnych $w$ celu wyboru środka o najlepszych parametrach, w funkcji temperatury, w zastosowaniu do przekładnika ciśnienia.

Podczas analizy wyników badań stwierdzono, że smar stosowany $\mathrm{w}$ przekładniku musi posiadać stabilne parametry $\mathrm{w}$ szerokim zakresie temperatur. Szczególnie w niskich temperaturach musi zachować możliwie płynną konsystencję. W związku z tym wprowadzono $\mathrm{w}$ odpowiednich układach przekładnika smar silikonowy, który posiada praktycznie niezmienną konsystencję $\mathrm{w}$ zakresie temperatur od $30{ }^{\circ} \mathrm{C}$ do $+40{ }^{\circ} \mathrm{C}$.

$\mathrm{Na}$ podstawie przeprowadzonych badań wybrano smar, który zastosowany w konkretnych elementach konstrukcji przekładnika ciśnienia, pozwala na jego poprwne i niezawodne funkcjonowanie. 


\section{Bibliography/Bibliografia}

[1] Kaluba M.: Przekładnik ciśnienia z automatyczna zmianq ciśnienia cylindrowego w funkcji ładunku dla pojazdów szynowych. Zeszyty Naukowe Instytutu Pojazdów. Warszawa 2010

[2] PL-12DC karta katalogowa

[3] Strona internetowa: http://www.inkom.com.pl/produkt/items/631

[4] Strona internetowa: www.skf.com.pl

[5] Tomaszewski F., Tomaszewski S.: Dobór elementów przekładnika ciśnienia i ich wpływ na parametry pracy. Pojazdy Szynowe 4/2014

[6] Tomaszewski S.: „Relacje diagnostyczne stan - sygnat przekładników ciśnienia układów hamulcowych pojazdów szynowych”. Rozprawa doktorska. Poznań 2017 